\title{
Drosophila comet assay: insights, uses, and future perspectives
}

\author{
Isabel Gaivão ${ }^{1}$ and L. María Sierra ${ }^{2}$ * \\ 'Department of Genetics and Biotechnology, Animal and Veterinary Research Centre, University of Trás-os-Montes and Alto Douro, Vila Real, Portugal \\ ${ }^{2}$ Área de Genética, Departamento de Biología Funcional, and Instituto Universitario de Oncología del Principado de Asturias, Universidad de Oviedo, Oviedo, \\ Spain
}

\section{Edited by:}

Rajib Bandopadhyay, Birla Institute of Technology, India

\section{Reviewed by:}

Andrey Cherstry, Institute of Complex Systems - Research Center Juelich, Germany

James M. Ford, Stanford University School of Medicine, USA

${ }^{*}$ Correspondence:

L. María Sierra, Área de Genética, Departamento de Biología Funcional, and Instituto Universitario de Oncología del Principado de Asturias, Universidad de Oviedo, C/ Julián Clavería s/n, 33006 Oviedo, Asturias, Spain

e-mail:Imsierra@uniovi.es
The comet assay, a very useful tool in genotoxicity and DNA repair testing, is being applied to Drosophila melanogaster since around 15 years ago, by several research groups. This organism is a valuable model for all kind of processes related to human health, including DNA damage response. The assay has been performed mainly in vivo using different larvae cell types (from brain, midgut, hemolymph, and imaginal disk), but also in vitro with the S2 cell line. Since its first application, it has been used to analyze the genotoxicity and action mechanisms of different chemicals, demonstrating good sensitivity and proving its usefulness. Moreover, it is the only assay that can be used to analyze DNA repair in somatic cells in vivo, comparing the effects of chemicals in different repair strains, and to quantitate repair activities in vitro. Additionally, the comet assay in Drosophila, in vivo and in vitro, has been applied to study the influence of protein overexpression on genome integrity and degradation. Although the assay is well established, it could benefit from some research to determine optimal experimental design to standardize it, and then to allow comparisons among laboratories independently of the chosen cell type.

Keywords: Drosophila, comet assay, neuroblast cells, hemocytes, midgut cells, genotoxicity, DNA repair

\section{INTRODUCTION}

The single cell gel electrophoresis test, or comet assay, was originally developed by Östling and Johanson (1984) as a microelectrophoretic technique to visualize DNA damage in single cells. Subsequently it was improved by Singh et al. (1988), and since then so extensively used that some working-groups were created to standardize its application to mammal and human cells studies (Burlinson et al., 2007; Karlsson, 2010; Azqueta and Collins, 2013; Ersson et al., 2013; Godschalk et al., 2013; Collins et al., 2014).

Its usefulness and easy performance lead to its rapid application to several fields, like genotoxicity analyses (Speit and Hartmann, 1999; Tice et al., 2000; Hartmann et al., 2003; Collins, 2004), human population biomonitoring (Collins et al., 1998; Somorovská et al., 1999; Kassie et al., 2000; Møller et al., 2000; Faust et al., 2004; Hoffmann et al., 2005; Burlinson et al., 2007; Dusinska and Collins, 2008; Uriol et al., 2013) and DNA repair (Collins and Horváthová, 2001; Collins etal., 2001; Collins and Gaivão, 2007; Gaivão et al., 2009; Dusinska and Collins, 2010). Because of this, it was also applied to other organisms, using different cell types (Menke et al., 2001; Dixon et al., 2002; Lee and Steinert, 2003; Jha, 2008; Dhawan et al., 2009; Ventura et al., 2013).

Surprisingly, its application to Drosophila melanogaster was rather late, despite the fact that this organism is one of the most valuable higher eukaryotic model organism, for all kind of processes and situations related to human health (Reiter et al., 2001; Koh et al., 2006; Wolf et al., 2006; Khurana et al., 2006; Rand, 2010), including the in vivo DNA damage response processes (Søndergaard, 1993; Vogel et al., 1999; Sekelsky et al., 2000; Vecchio, 2014).
The first attempt to apply the comet assay to Drosophila in vivo was performed by Gaivão (1999) in her Ph.D. Thesis, checking the availability of imaginal disk and brain ganglia cells. In the first published work, appeared 3 years later, the comet assay was performed with brain ganglia cells from third instar larvae (Bilbao et al., 2002). As with other organisms, several cell types, apart from the brain cells, have been used to carry out this assay in Drosophila in vivo, such as midgut cells (Mukhopadhyay et al., 2004; Siddique et al., 2005a; Sharma et al., 2011), hemocytes (Carmona et al., 2011a), and imaginal disk cells (Verma et al., 2012).

Most of these authors used the comet assay for its original purpose, the in vivo analyses of genotoxicity and DNA repair. But more recently, this assay has also been used to study genotoxicity in vitro (Guanggang et al., 2013), to analyze the influence of protein overexpression on genome integrity in vivo (Plyusnina et al., 2011; Brennan et al., 2012; Verma et al., 2012) and in vitro (Radyuk et al., 2006), and very recently to quantitate DNA repair activity in vitro (Rodríguez et al., submitted).

In this mini-review we aim to present available information about the comet assay in Drosophila; outlining the type of cells and insights into its technical performance, its uses in vivo and in vitro, and its spread availability as a useful tool and future perspectives.

\section{INSIGHTS \\ BRAIN CELLS}

The Drosophila comet assay using brain ganglia cells was developed at the University of Oviedo (Spain) by Isabel Gaivão and the group of L. María Sierra and M. A. Comendador (Gaivão, 1999; 
Bilbao et al., 2002). Our aim was to develop a tool to study both genotoxicity and in vivo DNA repair in somatic cells.

The developed protocol included the use of third instar larvae (developed $24 \mathrm{~h}$ at $24^{\circ} \mathrm{C}$ and five additional days at $21^{\circ} \mathrm{C}$ ) treated in the food during $12 \mathrm{~h}$. Brain ganglia were extracted, and cells were mechanically individualized, shredding the tissue with tungsten wires, and suspended in Ringer's buffer (Bilbao et al., 2002; García-Sar et al., 2008, 2012; Rodríguez et al., submitted). Cells were embedded in $0.5 \%$ low melting point agarose (LMPA), three agarose layers were prepared, and cells were disrupted during $2 \mathrm{~h}$ with a lysis solution containing $N$-lauroylsarcosine sodium salt (N-LS), $0.77 \%$, and dimethyl sulfoxide (DMSO)

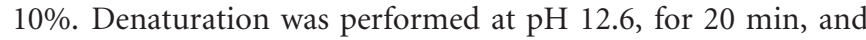
electrophoresis was set at $0.9 \mathrm{~V} / \mathrm{cm}$, for $20 \mathrm{~min}$. After neutralization and fixation, slides were stained with ethidium bromide $(0.4 \mu \mathrm{g} / \mathrm{mL})$, with Vectashield ${ }^{\circledR}$ fluorescence protector (Vector Laboratories, Inc., Burlingame, CA, USA) to avoid fluorescence decay (Table 1). A very detailed protocol was recently published (Sierra et al., 2014).

Microscope photos were analyzed with the Komet 5 software program (Kinetic, England), collecting data on \% tail DNA, tail length, and tail moment, although the analyses were carried out with the tail moment parameter because it increased linearly with the amount of DNA damage and was the best to detect statistically significant differences. The wild-type OregonK Drosophila strain was used as a standard, since it is rather sensitive to the action of DNA damaging agents in somatic cells (Gaivão and Comendador, 1996). Under all these conditions, the comet assay yielded spontaneous DNA damage measurements of $6.5 \pm 0.5$ for tail moment and of $30 \pm 1.25$ for $\%$ tail DNA.

Recently, we have developed a technical variation of this protocol to be able to quantitate DNA repair activities in vitro. This variant consists on the incubation of nucleoid DNA with cell-free protein extracts from repair-efficient and deficient-strains, after the lysis step (Rodríguez et al., submitted).

Plyusnina et al. (2011) also used brain cells to perform the comet assay. They disaggregated them mechanically in Poels' salt solution (PSS). Cells were embedded in 0.75\% LMPA, lysis was performed for $1 \mathrm{~h}$, with a buffer without $N$-LS or DMSO. Denaturation was carried out at $\mathrm{pH} 13$ for $10 \mathrm{~min}$, followed by electrophoresis at $15 \mathrm{~V}-300 \mathrm{~mA}$ for $10 \mathrm{~min}$. Nuclei were stained with acridine orange. Comet images were analyzed with the Comet Score ${ }^{\mathrm{TM}}$ software (TriTek Corporation, USA), and the parameter for analysis was the Olive tail moment. The wild-type strain was Canton-S and the values of spontaneous DNA damage measurements were approximately 1.2 units of the analyzed parameter.

\section{HEMOCYTES}

The comet assay using hemocytes from Drosophila was developed by the group of R. Marcos at the Autonomous University of Barcelona (Spain). In this protocol, $72 \pm 2 \mathrm{~h}$ old larvae (developed at $24^{\circ} \mathrm{C}$ ) were treated for $24 \mathrm{~h}$. Since hemocytes are individual cells, they were just collected in phosphate buffered saline (PBS), with 0.07\% phenylthiourea (Carmona et al., 2011a,b,c; Sabella etal., 2011).
Cells were embedded in $0.75 \%$ LMPA, and two agarose layers were prepared. Lysis buffer contained N-LS 1\% (Carmona et al., 2011 a,b,c), or DMSO 10\% (Sabella et al., 2011). Lysis time was $2 \mathrm{~h}$. Small variations on the denaturation time and the electrophoresis conditions were performed (Table 1). Nucleoids were stained with DAPI $(1 \mu \mathrm{g} / \mathrm{mL})$. Detailed protocols for this assay are available (Marcos and Carmona, 2013; Sierra et al., 2014).

Comets were analyzed with the Komet 5 software program, and results were mostly expressed as \% tail DNA (Carmona et al., 2011a,b,c), although DNA damage was also measured as percentage of damaged nuclei (Sabella et al., 2011). The standard wild-type strain used was OregonR, an insecticide resistant strain with high levels of cytochrome P450 and xenobiotic metabolism (Hällström et al., 1984). With this protocol, the highest \% tail DNA detected for spontaneous DNA damage was $18.93 \pm 0.84$ (Carmona et al., 2011c).

\section{MIDGUT CELLS}

The comet assay with midgut cells was developed by the group of A. Dhawan and D. K. Chowdhuri at the CSIR-Indian Institute of Toxicology Research, formerly Industrial Toxicology Research Center (India). They also developed the enzymatic brain cell disaggregation protocol. Mid-gut tissue, with or without brain ganglia, from third instar larvae treated for different times were explanted in PSS buffer. Cells were enzymatically individualized, incubating $15 \mathrm{~min}$ with collagenase $(0.5 \mathrm{mg} / \mathrm{mL})$ in PBS. Treatment times varied from 12 to $74 \mathrm{~h}$ (Table 1; Mukhopadhyay et al., 2004; Siddique et al., 2005a,b, 2008, 2013; Mishra et al., 2011, 2013, 2014; Sharma et al., 2011, 2012; Shukla et al., 2011).

Cells were embedded in $0.75 \%$ LMPA, with two or three agarose layers. Lysis buffer did not contained N-LS, or DMSO, and lysis time was $2 \mathrm{~h}$. As presented in Table 1, the denaturation step was mainly performed at $\mathrm{pH}>13$ during $10 \mathrm{~min}$, although in two works this step was performed at neutral conditions, pH 8.5 for $60 \mathrm{~min}$ (Sharma et al., 2011; Mishra et al., 2013). In these two cases electrophoresis was also set up differently from the more standard $0.7 \mathrm{~V} / \mathrm{cm}$ during $15 \mathrm{~min}$ (Table 1). Staining was carried out with ethidium bromide $(20 \mu \mathrm{g} / \mathrm{mL})$, for $10 \mathrm{~min}$.

Some of the works carried out at the CSIR-Indian Institute of Toxicology Research analyzed three comet parameters, $\%$ tail DNA, tail length, and Olive tail moment (Mukhopadhyay et al., 2004; Siddique et al., 2005a,b), and in others only the \% tail DNA was used for result analyses. The Komet 5 software program was throughout used for photo analysis, except by Siddique etal. (2013), who used the Comet Score $^{\mathrm{TM}}$ software, v1.5, to analyze tail length. The standard wild-type strain was OregonR. With this protocol, \% tail DNA varied from 6 to $10 \%$, with errors lower than $1 \%$, and Olive tail moment varied from 0.7 to 1.5 , with errors under 0.12 .

\section{IMAGINAL DISK CELLS}

Imaginal disk cells have also been used to carry out the comet assay in vivo in Drosophila (Verma etal., 2012). In this case, cell disaggregation was performed enzymatically, as described earlier for midgut cells (see Midgut Cells). 


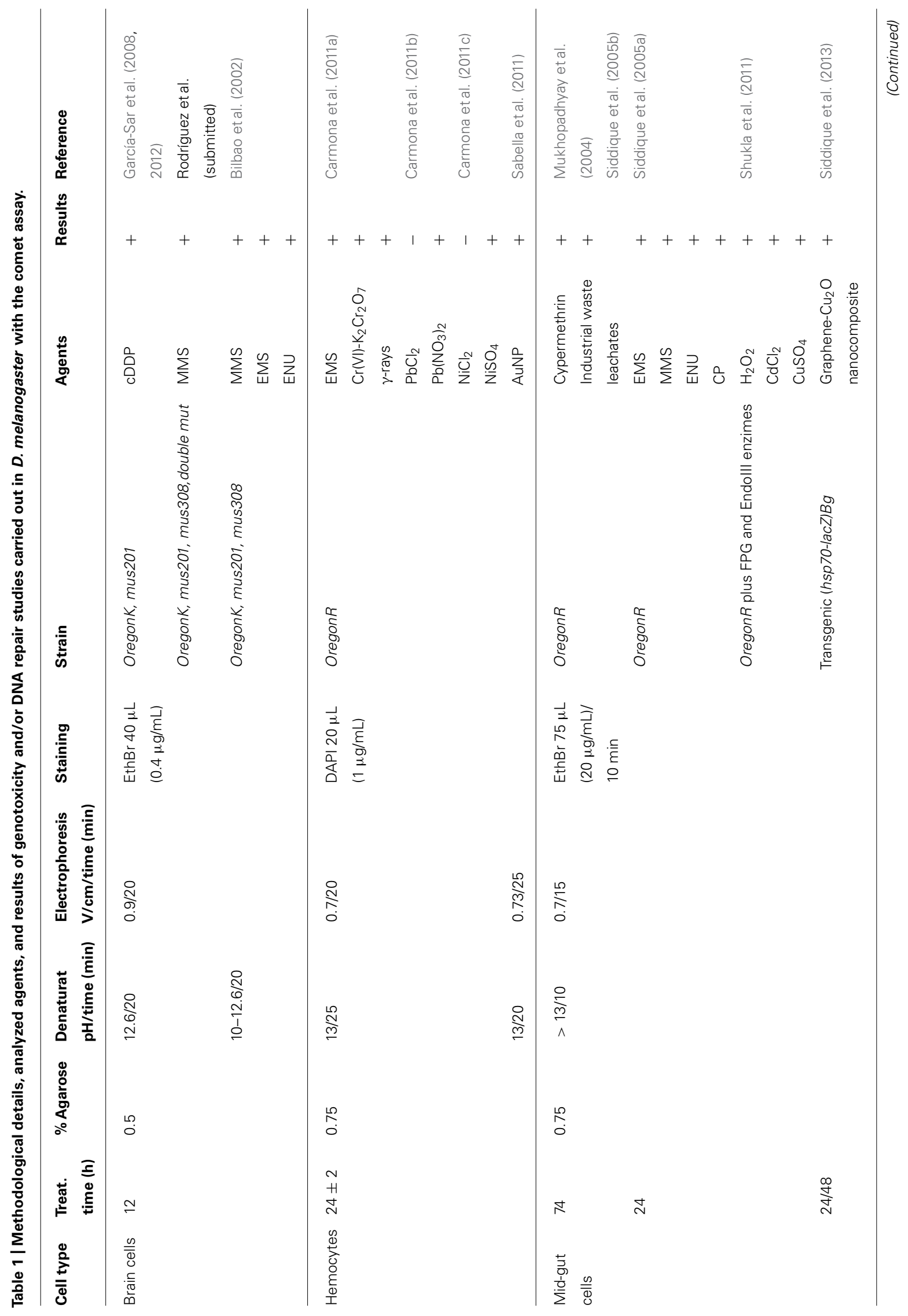




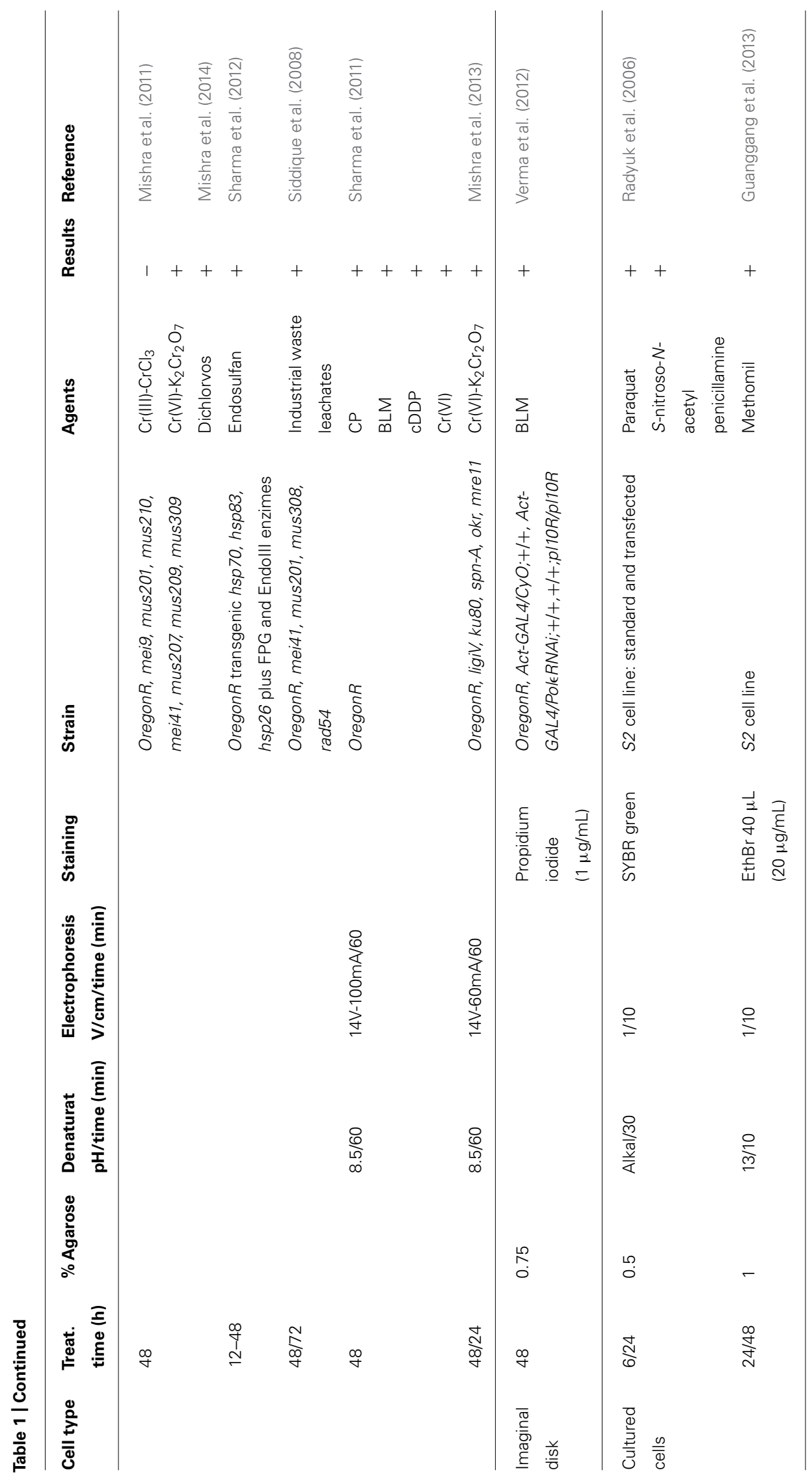


The conditions of the comet assay were also those described above (see Midgut Cells) with two exceptions: the lysis buffer contained DMSO $10 \%$, and nuclei were stained with propidium iodide $(1 \mu \mathrm{g} / \mathrm{mL})$. Photos were analyzed with the Comet Score ${ }^{\mathrm{TM}}$ software, and DNA damage was quantified using the \% tail DNA parameter. The wild-type strain used was OregonR, and the spontaneous values of \% tail DNA were around 7 (only a graph was presented).

\section{OTHER CELLS}

Spermatocytes were other cell type chosen to perform the comet assay in vivo, in this case from D. simulans (Brennan et al., 2012). Testes were dissected in PBS. However, with respect to the comet assay, the only information available from this work is that they have used the OxiSelect Comet Assay Kit (from Cell BioLabs, San Diego, CA, USA) to perform it, the Comet Score ${ }^{\mathrm{TM}}$ software for image analysis, and a classification of \% tail DNA in five categories for the analysis of results.

The comet assay in Drosophila was also performed in vitro using S2 cultured cells (Radyuk et al., 2006; Guanggang et al., 2013). Cells were treated for $24 \mathrm{~h}$, embedded in 0.5\% LMPA, lysed for $30 \mathrm{~min}$, denatured in alkaline conditions for $30 \mathrm{~min}$, electrophoresed at $1 \mathrm{~V} / \mathrm{cm}$ for $10 \mathrm{~min}$, and stained with SYBR green dye; and the DNA damage was measured classifying the damaged cells in four categories (Radyuk et al., 2006).

Alternatively, cells were treated for 24 or $48 \mathrm{~h}$ and embedded in 1\% LMPA. Lysis buffer contained DMSO 10\%, and lysis time was $30 \mathrm{~min}$. Denaturation at $\mathrm{pH} 13$ for $10 \mathrm{~min}$ was followed by electrophoresis $1 \mathrm{~V} / \mathrm{cm}$ for $10 \mathrm{~min}$. Nucleoids were stained with ethidium bromide $(20 \mu \mathrm{g} / \mathrm{mL})$, and comet photos were analyzed with CASP image analysis system, measuring \% tail DNA and tail moment. The values of these parameters for spontaneous DNA damage were $11.57 \pm 5.84$ for $\%$ tail DNA and $2.20 \pm 1.24$ for tail moment (Guanggang et al., 2013).

\section{USES}

\section{GENOTOXICITY AND DNA REPAIR ANALYSIS}

It is possible to study DNA repair in vivo in Drosophila germ cells, male and female ones, since many years ago (Vogel et al., 1996; Hernando et al., 2004). However, it was not possible to study it in somatic cells, with the available in vivo SMART assays (Vogel and Nivard, 2001). Because of this, our main aim when designing the first comet assay protocol in Drosophila was to develop a tool to study DNA repair in vivo in somatic cells (Gaivão, 1999; Bilbao et al., 2002). Consequently, many (but not all) of the works carried out with this assay in Drosophila were aimed to study genotoxicity and/or DNA repair in somatic cells in vivo.

In addition to its use in the assay design, using model genotoxic agents, and efficient and deficient repair strains (Bilbao et al., 2002), brain cells, obtained with the University of Oviedo protocol, were used to demonstrate the relationship between cisplatin induced adducts and DNA strand breaks (García-Sar et al., 2008), and the influence of the nucleotide excision repair system in this relationship, with the in vivo comet repair assay (García-Sar et al., 2012). Very recently, brain cells have been used to implement the in vitro comet repair assay in Drosophila, to be able to quantitate DNA repair activities in vitro (Gaivão et al., 2014), and it was used to check the repair activity of cell free protein extracts obtained from wild-type and repair mutant strains in the repair of methyl methanesulfonate induced DNA damage (Rodríguez et al., submitted).

After checking their use with known inducers of DNA strand breaks (Carmona et al., 2011a), hemocytes were used to demonstrate that not all the salts of lead and nickel were genotoxic (Carmona et al., 2011b,c), but that gold nanoparticles were so (Sabella et al., 2011).

Midgut cells, with or without brain cells, have been used to study oxidative DNA damage, using incubations with FPG and Endo III enzymes (Shukla et al., 2011; Sharma et al., 2012), and to demonstrate the genotoxicity of chromium salts (Mishra et al., 2011, 2013; Sharma etal., 2011), pesticides like cypermethrin (Mukhopadhyay et al., 2004), endosulfan (Sharma et al., 2012), and dichlorvos (Mishra et al., 2014), contaminants as industrial waste leachates (Siddique et al., 2005b, 2008), and nanomaterials like graphene copper nanocomposite (Siddique et al., 2013). In addition, some of these genotoxic agents, like chromium salts, dichlorvos, and industrial waste leachates, were analyzed in different repair conditions, with the in vivo comet repair assay (Siddique etal., 2008; Mishra etal., 2011, 2013, 2014), checking the influence of pre- and post-replication DNA repair pathways on their genotoxicity. Other genotoxic agents, like endosulfan and graphene copper nanocomposite, were analyzed in transgenic strains for genes encoding heat shock proteins (hsp), to check responses to xenobiotic stress, and influence of xenobiotic metabolism (Sharma etal., 2012; Siddique et al., 2013).

Analysis of genotoxicity, specifically that of the insecticide methomil, was also the aim of the comet assay performed in vitro with S2 culture cells (Guanggang et al., 2013).

\section{OTHER USES}

In addition to these studies of genotoxicity and DNA repair, the comet assay in vivo in Drosophila had been used to study: (i) the influence of GADD45 protein over-expression on longevity and spontaneous DNA damage, as an indication of increased DNA repair activity (Plyusnina et al., 2011); (ii) chromatin integrity in DNA pole mutants exposed to bleomycin (Verma et al., 2012); and (iii) oxidative DNA damage in spermatocytes of Wolbachiainfected D. simulans flies (Brennan et al., 2012).

Furthermore, the comet assay in vitro was used to check the effect of mitochondria ectopic over-expression of dOgg 1 and RpS3 proteins on DNA degradation after oxidative damage induction (Radyuk et al., 2006).

\section{FUTURE PERSPECTIVES}

Considering the relevance of $D$. melanogaster as an established insect model for human diseases and toxicological research, recommended by the European Centre for the Validation of Alternative Methods (ECVAM), all the results of in vivo genotoxicity studies with this organism should be considered as relevant for human health. In this aspect, the comet assay performed in vivo is even more important because, in addition to its high sensitivity, it is the only assay that allows the analysis of DNA repair in somatic cells. And, at least theoretically, the comet 
assay results should be more easily and directly compared among species.

There is however a possible problem: there are several groups using different protocols, what make comparisons even among Drosophila laboratories impossible. So, it is necessary to standardize the basic comet assay protocol. Azqueta etal. (2011) demonstrated in human cells how small changes in some variables, such as agarose concentration, alkaline unwinding time, or electrophoresis conditions, might significantly affect the results. And these are specifically some of the variables that differ between the protocol for brain cells and the rest: LMPA percentage $(0.5$ vs. $0.75 \%$ ), lysis buffer composition ( $N$-LS and DMSO vs. only $N$-LS or none of them), or denaturation and electrophoresis conditions (more $\mathrm{V} / \mathrm{cm}$, compared to the protocol for hemocytes, and more denaturation time and $\mathrm{V} / \mathrm{cm}$, compared to the protocol for midgut cells). These differences might explain the higher values of the comet parameters, for spontaneous DNA damage, found with the brain cell protocol, compared to the others, because although some differences might be attributed to the wild-type strain analyzed (OregonK is more sensitive than OregonR), at least in the case of human cells differences due to individuals or cell types were not so relevant (Azqueta et al., 2011). It is then necessary to study the effects of these differences and whether a higher sensitivity is an advantage or a disadvantage.

To help with the required standardization, some of the protocol optimizations performed for other cells and organisms can be tested and applied to Drosophila, including its simplification (number of layers, size of gels, or solution compositions) and the high throughput versions, recently developed based on the use of 12 mini-gels on one slide (Shaposhnikov et al., 2010). Additionally, the modified comet assay performed incubating with repair lesionspecific enzymes, as used by Shukla et al. (2011) and Sharma et al. (2012) for oxidative damage, can be extended to other types of damages and repair systems (Collins et al., 2008). This standardization would also clearly help the use of this assay in other types of studies, different from genotoxicity and DNA repair testing.

\section{REFERENCES}

Azqueta, A., and Collins, A. R. (2013). The essential comet assay: a comprehensive guide to measuring DNA damage and repair. Arch. Toxicol. 87, 949-968. doi: 10.1007/s00204-013-1070-0

Azqueta, A., Gutzkow, K. B., Brunborg, G., and Collins, A. R. (2011). Towards a more reliable comet assay; Optimising agarose concentration, unwinding time and electrophoresis conditions. Mutat. Res. 724, 41-45. doi: 10.1016/j.mrgentox.2011.05.010

Bilbao, C., Ferreiro, J. A., Comendador, M. A., and Sierra, L. M. (2002). Influence of mus201 and mus308 mutations of Drosophila melanogaster on the genotoxicity of model chemicals in somatic cells in vivo measured with the comet assay. Mutat. Res. 503, 11-19. doi: 10.1016/S0027-5107(02)00070-2

Brennan, L. J., Haukedal, J. A., Earle, J. C., Keddie, B., and Harris, H. L. (2012). Disruption of redox homeostasis leads to oxidative DNA damage in spermatocytes of Wolbachia-infected Drosophila simulans. Insect Mol. Biol. 21, 510-520. doi: 10.1111/j.1365-2583.2012.01155.x

Burlinson, B., Tice, R. R., Speit, G., Agurell, E., Brendler-Schwaab, S. Y., Collins, A. R., et al. (2007) In vivo comet assay workgroup, part of the fourth international workgroup on genotoxicity testing: results of the in vivo comet assay workgroup. Mutat. Res. 627:31-35. doi: 10.1016/j.mrgentox.2006.08.011

Carmona, E. R., Guecheva, T. N., Creus, A., and Marcos, R. (2011a). Proposal of an in vivo comet assay using hemocytes of Drosophila melanogaster. Environ. Mol. Mutagen. 52, 165-169. doi: 10.1002/em.20604
Carmona, E. R., Creus, A., and Marcos, R. (2011b). Genotoxic effects of two nickelcompounds in somatic cells of Drosophila melanogaster. Mutat. Res. 718, 33-37. doi: 10.1016/j.mrgentox.2010.10.008

Carmona, E. R., Creus, A., and Marcos, R. (2011c). Genotoxicity testing of two lead-compounds in somatic cells of Drosophila melanogaster. Mutat. Res. 724, 35-40. doi: 10.1016/j.mrgentox.2011.05.008

Collins, A. R. (2004). The Comet assay for DNA damage and repair. principles, applications, and limitations. Mol. Biotechnol. 26, 249-261. doi: 10.1385/MB:26:3:249

Collins, A. R., Azqueta, A., Brunborg, G., Gaivão, I., Giovannelli, L., Kruszewski, M., et al. (2008). The comet assay: topical issues. Mutagenesis 23, 143-151. doi: 10.1093/mutage/gem051

Collins, A. R., Dusinska, M., Horvathova, E., Munro, E., Savio, M., and Stetina, R. (2001). Inter-individual differences in DNA base excision repair activity measured in vitro with the comet assay. Mutagenesis 16, 297-301. doi: 10.1093/mutage/16.4.297

Collins, A. R., and Gaivão, I. (2007). DNA base excision repair as a biomarker in molecular epidemiology studies. Mol. Aspects Med. 28, 307-322. doi: 10.1016/j.mam.2007.05.005

Collins, A. R., Gedik, C. M., Olmedilla, B., Southon, S., and Bellizi, M. (1998). Oxidative DNA damage measured in human lymphocytes; large differences between sexes and between countries, and correlations with heart disease mortality rates. FASEB J. 12, 1397-1400.

Collins, A. R., and Horváthová, E. (2001). Oxidative DNA damage, antioxidants and DNA repair: applications of the comet assay. Biochem. Soc. Trans. 29, 337-341. doi: 10.1042/BST0290337

Collins, A., Koppen, G., Valdiglesias, V., Dusinska, M., Kruszewski, M., Møller, P., et al. (2014). The comet assay as a tool for human biomonitoring studies: the ComNet project. Mutat. Res. Rev. Mutat. Res. 759, 27-39. doi: 10.1016/j.mrrev.2013.10.001

Dhawan, A., Bajpayee, M., and Parmar, D. (2009). Comet assay: a reliable tool for the assessment of DNA damage in different models. Cell Biol. Toxicol. 25, 5-32. doi: 10.1007/s10565-008-9072-Z

Dixon, D. R., Pruski, A. M., Dixon, L. R. J., and Jha, A. N. (2002). Marine invertebrate eco-genotoxicology: a methodological overview. Mutagenesis 17, 495-507. doi: 10.1093/mutage/17.6.495

Dusinska, M., and Collins, A. R. (2008). The comet assay in human biomonitoring: gene-environment interactions. Mutagenesis 23, 191-205. doi: 10.1093/mutage/gen007

Dusinska, M., and Collins, A. R. (2010) "DNA oxidation, antioxidant effects, and DNA repair measured with the comet assay," in Biomarkers for Antioxidant Defense and Oxidative Damage: Principles and Practical Applications, eds G. Aldini, K. J. Yeum, E. Niki, and R. Russell (Oxford: Blackwell Publishing Ltd), 261-282.

Ersson, C., Møller, P., Forchhammer, L., Loft, S., Azqueta, A., Godschalk, R. W., et al. (2013). An ECVAG inter-laboratory validation study of the comet assay: inter-laboratory and intra-laboratory variations of DNA strand breaks and FPG-sensitive sites in human mononuclear cells. Mutagenesis 28, 279-286. doi: 10.1093/mutage/get001

Faust, F., Kassie, F., Knasmüller, S., Boedecker, R. H., Mann, M., and Mersch-Sundermann, V. (2004). The use of the alkaline comet assay with lymphocytes in human biomonitoring studies. Mutat. Res. 566, 209-229. doi: 10.1016/j.mrrev.2003.09.007

Gaivão, I. (1999) Genotoxic Evaluation of Reactive Oxygen Species Generatig Compounds: A Study in Drosophila melanogaster. Ph.D. thesis, Universidade de Trás-Os-Montes and Alto Douro, Vila Real.

Gaivão, I., and Comendador, M. A. (1996) The $w / w+$ somatic mutation and recombination test (SMART) of Drosophila melanogaster for detecting reactive oxygen species: characterization of 6 strains. Mutat. Res. 360, 145-151. doi: 10.1016/0165-1161(96)00003-9

Gaivão, I., Piasek, A., Brevik, A., Shaposhnikov, S., and Collins, A. R. (2009). Comet assay-based methods for measuring DNA repair in vitro; estimates of inter- and intra-individual variation. Cell. Biol. Toxicol. 25, 45-52. doi: 10.1007/s10565-0079047-5

Gaivão, I., Rodriguez, R., and Sierra, L. M. (2014). "Use of the comet assay to study DNA repair in Drosophila melanogaster," in Genotoxicity and DNA Repair: A Practical Approach, Methods in Pharmacology and Toxicology, eds L. M. Sierra and I. Gaivão (New York: Springer). doi: 10.1007/978-1-4939-1068-7_16

García-Sar, D., Aguado, L., Montes-Bayón, M., Comendador, M. A., Blanco González, E., Sanz-Medel, A., et al. (2012). Relationships between 
cisplatin-induced adducts and DNA strans-breaks, mutation and recombination in vivo in somatic cells of Drosophila melanogaster, under different conditions of nucleotide excision repair. Mutat. Res. 741, 81-88. doi: 10.1016/j.mrgentox.2011.11.005

García-Sar, D., Montes-Bayón, M., Aguado Ortiz, L., Blanco-Gonzalez, E., Sierra L. M., and Sanz-Medel, A. (2008) In vivo detection of DNA adducts induced by cisplatin using capillary HPLC-ICP-MS and their correlation with the genotoxic damage in Drosophila melanogaster. Anal. Biol. Chem. 390, 37-44. doi 10.1007/s00216-007-1634-z

Godschalk, R. W., Ersson, C., Riso, P., Porrini, M., Langie, S. A., van Schooten, F. J., etal. (2013). DNA-repair measurements by use of the modified comet assay: an inter-laboratory comparison within the European Comet Assay Validation Group (ECVAG). Mutat. Res. 757, 60-67. doi: 10.1016/j.mrgentox.2013. 06.020

Guanggang, X., Diqiu, L., Jianzhong, Y., Jingmin, G., Huifeng, Z., Mingan, S., et al. (2013). Carbamate insecticide methomyl confers cytotoxicity through DNA damage induction. Food Chem. Toxicol. 53, 352-358. doi 10.1016/j.fct.2012.12.020

Hällström, I., Blank, A., and Atuma, S. (1984). Genetic variation in cytochrome P450 and xenobiotic metabolism in Drosophila melanogaster. Biochem. Pharmacol. 33 , 13-20. doi: 10.1016/0006-2952(84)90364-2

Hartmann, A., Agurell, E., Beevers, C., Brendler-Schwaab, S., Burlinson, B., Clay, P., et al. (2003). Recommendations for conducting the in vivo alkaline comet assay. Mutagenesis 18, 45-51. doi: 10.1093/mutage/18.1.45

Hernando, J., Alvarez, L., Ferreiro, J. A., Sancho, I., Comendador, M. A., and Sierra L. M. (2004). Female germ cell mutagenicity of model chemicals in Drosophila melanogaster: mechanistic information and analysis of repair systems. Mutat. Res. 545, 59-72. doi: 10.1016/j.mrfmmm.2003.09.013

Hoffmann, H., Högel, J., and Speit, G. (2005). The effect of smoking on DNA effects in the comet assay: a meta-analysis. Mutagenesis 20, 455-466. doi: 10.1093/mutage/gei064

Jha, A. N. (2008). Ecotoxicological applications and significance of the comet assay. Mutagenesis 23, 207-221. doi: 10.1093/mutage/gen014

Karlsson, H. L. (2010). The comet assay in nanotoxicology research. Anal. Bioanal. Chem. 398, 651-666. doi: 10.1007/s00216-010-3977-0

Kassie, F., Parzefall, W., and Knasmüller, S. (2000). Single cell gel electrophoresis assay: a new technique for human biomonitoring studies. Mutat. Res. 463, 13-31. doi: 10.1016/S1383-5742(00)00041-7

Khurana, V., Lu, Y., Steinhilb, M. L., Oldham, S., Shulman, J. M., and Feany, M. B. (2006). TOR-mediated cell-cycle activation causes neurodegeneration in a Drosophila tauopathy model. Curr. Biol. 16, 230-241. doi: 10.1016/j.cub.2005.12.042

Koh, K., Evans, J. M., Hendricks, J. C., and Sehagal, A. (2006). A Drosophila mode for age associated changes in sleep: wake cycles. Proc. Natl. Acad. Sci. U.S.A. 103, 13843-13847. doi: 10.1073/pnas.0605903103

Lee, R. F., and Steinert, S. (2003). Use of the single cell gel electrophoresis/come assay for detecting DNA damage in aquatic (marine and freshwater) animals. Mutat. Res. 544, 43-64. doi: 10.1016/S1383-5742(03)00017-6

Marcos, R., and Carmona, E. R. (2013). The wing-spot and the comet tests as useful assays detecting genotoxicity in Drosophila. Methods Mol. Biol. 1044, 417-427. doi: 10.1007/978-1-62703-529-3_23

Menke, M., Chen, I.-P., Angelis, K. J., and Schubert, I. (2001). DNA damage and repair in Arabidopsis thaliana as measured by the comet assay after treatment with different classes of genotoxins. Mutat. Res. 493, 87-93. doi: 10.1016/S13835718(01)00165-6

Mishra, M., Sharma, A., Negi, M. P., Dwivedi, U. N., and Chowdhuri, D. K. (2011). Tracing the tracks of genotoxicity by trivalent and hexavalent chromium in Drosophila melanogaster. Mutat. Res. 722, 44-51. doi: 10.1016/j.mrgentox.2011.02.010

Mishra, M., Sharma, A., Shukla, A. K., Kumar, R., Dwivedi, U. N., and Chowdhuri, D. K. (2014) Genotoxicity of dichlorvos in strains of Drosophila melanogaster defective in DNA repair. Mutat. Res. 766, 35-41. doi: 10.1016/j.mrgentox.2014. 02.004

Mishra, M., Sharma, A., Shukla, A. K., Pragya, P., Murthy, R. C., de Pomerai, D., etal. (2013). Transcriptomic analysis provides insights on hexavalent chromium induced DNA strand breaks and their possible repair in midgut cells of Drosophila melanogaster larvae. Mutat. Res. 747-748, 28-39. doi: 10.1016/j.mrfmmm.2013.04.005
Møller, P., Knudsen, L. E., Loft, S., and Wallin, H. (2000). The comet assay as a rapid test in biomonitoring occupational exposure to DNA-damaging agents and effect of confounding factors. Cancer Epidemiol. Biomarkers 9, 1005-1015.

Mukhopadhyay, I., Chowdhuri, D. K., Bajpayee, M., and Dhawan, A. (2004). Evaluation of in vivo genotoxicity of cypermethrin in Drosophila melanogaster using the alkaline comet assay. Mutagenesis 19, 85-90. doi: 10.1093/mutage/geh007

Östling, O., and Johanson, K. J. (1984). Microelectrophoretic study of radiationinduced DNA damages in individual mammalian cells. Biochem. Biophys. Res. Commun. 123, 291-298. doi: 10.1016/0006-291X(84)90411-X

Plyusnina, E. N., Shaposhnikov, M. V., and Moskalev, A. A. (2011). Increase of Drosophila melanogaster lifespan due to D-GADD45 overexpression in the nervous system. Biogerontology 12, 211-226. doi: 10.1007/s10522-010-9311-6

Radyuk, S. N., Michalak, K., Rebrin, I., Sohal, R. S., and Orr, W. C. (2006). Effects of ectopic expression of Drosophila DNA glycosylases dOgg1 and RpS3 in mitochondria. Free Radic. Biol. Med. 41, 757-764. doi: 10.1016/j.freeradbiomed.2006.05.021

Rand, M. D. (2010). Drosophotoxicology: the growing potential for Drosophila in neurotoxicology. Neurotoxicol. Teratol. 32, 74-83. doi: 10.1016/j.ntt.2009.06.004

Reiter, L. T., Potocki, L., Chien, S., Gribskov, M., and Bier, E. (2001). A systematic analysis of human disease-associated gene sequences in Drosophila melanogaster. Genome Res. 11, 1114-1125. doi: 10.1101/gr.169101

Sabella, S., Brunetti, V., Vecchio, G., Galeone, A., Maiorano, G., Cingolani, R., et al. (2011). Toxicity of citrate-capped AuNPs: an in vitro and in vivo assessment. J. Nanopart. Res. 13, 6821-6835. doi: 10.1007/s11051-011-0590-x

Sekelsky, J. J., Brodsky, M. H., and Burtis, K. C. (2000). DNA repair in Drosophila: insights from the Drosophila genome sequence. J. Cell. Biol. 150, F31-F36. doi: 10.1083/jcb.150.2.F31

Shaposhnikov, S., Azqueta, A., Henriksson, S., Gaivão, I., Huskisson, N. H., Smart, A., et al. (2010). Twelve-gel slide format optimised for comet assay and fluorescent in situ hybridisation. Toxicol. Lett. 195, 31-34. doi: 10.1016/j.toxlet.2010.02.017

Sharma, A., Mishra, M., Shukla, A. K., Kumar, R., Abdin, M. Z., and Chowdhuri, D. K. (2012). Organochlorine pesticide, endosulfan induced cellular and organismal response in Drosophila melanogaster. J. Hazard Mater. 221-222, 275-287. doi: 10.1016/j.jhazmat.2012.04.045

Sharma, A., Shukla, A. K., Mishra, M., and Chowdhuri, D. K. (2011). Validation and application of Drosophila melanogaster as an in vivo model for the detection of double strand breaks by neutral comet assay. Mutat. Res. 721, 142-146. doi: 10.1016/j.mrgentox.2011.01.010

Shukla, A. K., Pragya, P., and Chowdhuri, D. K. (2011). A modified alkaline comet assay for in vivo detection of oxidative DNA damage in Drosophila melanogaster. Mutat. Res. 726, 222-226. doi: 10.1016/j.mrgentox.2011.09.017

Siddique, H. R., Chowdhuri, D. K., Saxena, D. K., and Dhawan, A. (2005a). Validation of Drosophila melanogaster as an in vivo model for genotoxicity assessment using modified alkaline comet assay. Mutagenesis 20, 285-290. doi: 10.1093/mutage/gei032

Siddique, H. R., Gupta, S. C., Dhawan, A., Murthy, R. C., Saxena, D. K., and Chowdhuri, D. K. (2005b). Genotoxicity of industrial solid waste leachates in Drosophila melanogaster. Environ. Mol. Mutagen. 46, 189-197. doi: 10.1002/em.20149

Siddique, H. R., Sharma, A., Gupta, S. C., Murthy, R. C., Dhawan, A., Saxena, D. K., et al. (2008). DNA damage induced by industrial solid waste leachates in Drosophila melanogaster: a mechanistic approach. Environ. Mol. Mutagen. 49, 206-216. doi: 10.1002/em.20373

Siddique, Y. H., Fatima, A., Jyoti, S., Naz, F., Rahul, Khan, W., et al. (2013). Evaluation of the toxic potential of graphene copper nanocomposite (GCNC) in the third instar larvae of transgenic Drosophila melanogaster (hsp70-lacZ) $\mathrm{Bg}(9$.). PLoS ONE 8:e80944. doi: 10.1371/journal.pone.0080944

Sierra, L. M., Carmona, E. R., Aguado, L., and Marcos, R. (2014). "The comet assay in Drosophila: neuroblast and hemocyte cells," in Genotoxicity and DNA Repair: A Practical Approach, Methods in Pharmacology and Toxicology, eds L. M. Sierra and I. Gaivão (New York: Springer Science+Business Media). doi: 10.1007/978-1-4939-1068-7_15

Singh, N. P., McCoy, M. T., Tice, R. R., and Schneider, E. L. (1988). A simple technique for quantitation of low levels of DNA damage in individual cells. Exp. Cell. Res. 175, 184-191. doi: 10.1016/0014-4827(88)90265-0

Somorovská, M., Szabová, E., Vodicka, P., Tulinská, J., Barancoková, M., Fábry, R., et al. (1999). Biomonitoring of genotoxic risk in workers in a rubber factory: comparison of the comet assay with cytogenetic methods and immunology. Mutat. Res. 445, 181-192. doi: 10.1016/S1383-5718(99)00125-4 
Søndergaard, L. (1993). Homology between the mammalian liver and the Drosophila fat body. Trends Genet. 9, 193. doi: 10.1016/0168-9525(93)90113-V

Speit, G., and Hartmann, A. (1999). "The comet assay ( single cell gel test). A sensitive genotoxicity test for the detection of DNA damage and repair," in Methods in Molecular Biology, Vol. 113, DNA Repair Protocols: Eukaryotic Systems, ed. D. S. Henderson (Totowa, NJ: Humana Press Inc.), 203-212.

Tice, R. R., Agurell, E., Anderson, D., Burlinson, B., Hartmann, A., Kobayashi, H., etal. (2000). The single cell gel/comet assay: guidelines for in vitro and in vivo genetic toxicology testing. Environ. Mol. Mutagen. 35, 206-221. doi: 10.1002/(SICI) 1098-2280(2000)35:3<206::AID-EM8>3.0.CO;2-J

Uriol, E., Sierra, M., Comendador, M. A., Fra, J., Martínez-Camblor, P., Lacave, A. J., et al. (2013). Long-term biomonitoring of breast cancer patients under adjuvant chemotherapy: the comet assay as a possible predictive factor. Mutagenesis 28, 39-48. doi: 10.1093/mutage/ges050

Vecchio, G. (2014). A fruit fly in the nanoworld: once again Drosophila contributes to environment and human health. Nanotoxicology doi 10.3109/17435390.2014.911985 [Epub ahead of print].

Ventura, L., Giovannini, A., Savio, M., Donà, M., Macovei, A., Buttafava, A., etal. (2013). single cells gel electrophoresis (comet) assay with plants: research on DNA repair and ecogenotoxicity testing. Chemosphere 92, 1-9. doi: 10.1016/j.chemosphere.2013.03.006

Verma, A., Sengupta, S., and Lakhotia, S. C. (2012). DNApol-( gene is indispensable for the survival and growth of Drosophila melanogaster. Genesis 50, 86-101. doi: 10.1002/dvg.20791

Vogel, E. W., Graf, U., Frei, H. J., and Nivard, M. M. (1999). The results of assays in Drosophila as indicators of exposure to carcinogens. IARC Sci. Publ. 146, $427-470$.
Vogel, E. W., and Nivard, M. J. M. (2001). Phenotypes of Drosophila homologs of human XPF and XPG to chemically-induced DNA modifications. Mutat. Res. 476, 149-165. doi: 10.1016/S0027-5107(01)00121-X

Vogel, E. W., Nivard, M. J. M., Ballering, L. A. B., Bartsch, H., Barbin, A., Nair, J., et al. (1996). DNA damage and repair in mutagenesis and carcinogenesis: implications of structure-activity relationships for cross-species extrapolation. Mutat. Res. 353, 177-218. doi: 10.1016/0027-5107(96)00032-2

Wolf, M. J., Amrein, H., Izatt, J. A., Choma, M. A., Reedy, M. C., and Rockman, H. A. (2006). Drosophila as a model for the identification of genes causing adult human heart disease. Proc. Natl. Acad. Sci. U.S.A. 103, 1394-1399. doi: 10.1073/pnas.0507359103

Conflict of Interest Statement: The authors declare that the research was conducted in the absence of any commercial or financial relationships that could be construed as a potential conflict of interest.

Received: 10 June 2014; accepted: 14 August 2014; published online: 29 August 2014. Citation: Gaivão I and Sierra LM (2014) Drosophila comet assay: insights, uses, and future perspectives. Front. Genet. 5:304. doi: 10.3389/fgene.2014.00304

This article was submitted to Genomic Assay Technology, a section of the journal Frontiers in Genetics.

Copyright (c) 2014 Gaivão and Sierra. This is an open-access article distributed under the terms of the Creative Commons Attribution License (CC BY). The use, distribution or reproduction in other forums is permitted, provided the original author(s) or licensor are credited and that the original publication in this journal is cited, in accordance with accepted academic practice. No use, distribution or reproduction is permitted which does not comply with these terms. 